\title{
Rapid and Reproducible
} Differentiation of Hematopoietic and T Cell Progenitors From Pluripotent Stem Cells

OPEN ACCESS

Edited by:

Dan S. Kaufman

University of California, San Diego,

United States

Reviewed by:

Veronica Ramos-Mejia,

Junta de Andalucía de Genómica e Investigación Oncológica (GENYO),

Spain

Michael Coffey,

University of California, San Diego,

United States

${ }^{*}$ Correspondence:

Carole Guillonneau

carole.guillonneau@univ-nantes.fr

Laurent David

laurent.david@univ-nantes.fr

†These authors share first authorship

₹These authors share senior authorship

Specialty section:

This article was submitted to

Stem Cell Research,

a section of the journal

Frontiers in Cell and Developmental

Biology

Received: 29 June 2020

Accepted: 18 September 2020

Published: 20 October 2020

Citation:

Flippe L, Gaignerie A, Sérazin C. Baron O, Saulquin X, Themeli M, Guillonneau C and David L (2020)

Rapid and Reproducible

Differentiation of Hematopoietic and

$T$ Cell Progenitors From Pluripotent

Stem Cells.

Front. Cell Dev. Biol. 8:577464. doi: 10.3389/fcell.2020.577464

\author{
Léa Flippe ${ }^{1,2 t}$, Anne Gaignerie ${ }^{3 \dagger}$, Céline Sérazin ${ }^{1,2}$, Olivier Baron 4 , Xavier Saulquin ${ }^{5}$, \\ Maria Themeli ${ }^{6}$, Carole Guillonneau ${ }^{1,2 * \neq}$ and Laurent David ${ }^{1,2,3 * \neq}$
}

1 Université de Nantes, Inserm, Centre de Recherche en Transplantation et Immunologie, UMR 1064, ITUN, Nantes, France, 2 LabEx IGO "Immunotherapy, Graft, Oncology", Nantes, France, ${ }^{3}$ Université de Nantes, CHU Nantes, Inserm, CNRS, SFR Santé, FED 4203, Inserm UMS 016, CNRS UMS 3556, Nantes, France, ${ }^{4}$ Department of Pediatric Cardiac Surgery, University Hospital of Nantes, Nantes, France, ${ }^{5}$ Université de Nantes, CNRS, Inserm, CRCINA, Nantes, France,

${ }^{6}$ Department of Hematology, Cancer Center Amsterdam, Amsterdam University Medical Center (UMC), Amsterdam, Netherlands

Cell therapy using $T$ cells has revolutionized medical care in recent years but limitations are associated with the difficulty of genome editing of the cells, the production of a sufficient number of cells and standardization of the product. Human pluripotent stem cells (hPSCs) can self-renew and differentiate into $T$ cells to provide a standardized homogenous product of defined origin in indefinite quantity, therefore they are of great potential to alleviate limitations of therapeutic $T$ cell production. The differentiation of hPSCs takes place in two steps: first the induction of hematopoietic stem/progenitor cells (HSPCs), then the induction of lymphopoiesis by Notch signaling. However, the differentiation of $\mathrm{T}$ cells from hPSCs can be difficult and lack reproducibility. One parameter that needs to be better assessed is the potential of DLL1 vs. DLL4 ligands of the Notch pathway to induce T cells. In addition, culture of hPSCs is labor-intensive and not compatible with GMP production, especially when they are cultured on feeder cells. Thus, the definition of a robust GMP-compatible differentiation protocol from hPSCs cultured in feeder-free conditions would increase the accessibility to off-the-shelf hematopoietic and T cell progenitors derived from hPSCs. In this article, we describe an efficient, rapid and reproducible protocol for the generation of hematopoietic and $T$ cell progenitors in two steps: (1) generation of HSPCs from embryoid bodies (EB) in serum free medium and GMP-compatible feeder-free systems, (2) directed differentiation of hPSC-derived HSPCs into T-cell progenitors in the presence of bone marrow stromal cells expressing Notch-ligands OP9-DLL1 vs. OP9-DLL4.

Keywords: hiPSC, hESC, hematopoietic progenitor, T-cell progenitor, hematopoietic differentiation

\section{INTRODUCTION}

Immunotherapy offers novel opportunities for unmet therapeutic needs. The ability to use $\mathrm{T}$ cells to directly target tumors has proven extremely useful for treating hematological cancer, such as B cell lymphoma and multiple myeloma, and solid cancers, such as metastatic melanoma and carcinoma (Fournier et al., 2017). T cells with regulatory properties could also be used in the context of immunoregulation, for example for grafted patients. In that case, 
immune cells would be injected to induce tolerance for the graft, while preserving the immune response of grafted patients (Bézie et al., 2017, 2019; Flippe et al., 2019). Despite great potential, some limitations impair the development of T cell therapy. One limitation is that during the necessary amplification of $\mathrm{T}$ cells for treatment, T cells ability exhausts. This is reinforced in conditions where the patient's immune system is weakened by the treatment or the disease, thus precluding autologous $\mathrm{T}$ cell expansion. Another limitation is that $\mathrm{T}$ cells are difficult to edit, limiting their use with engineered antigen receptors. Altogether, T cell therapy is powerful but limited by the intrinsic nature of specialized cells (Nianias and Themeli, 2019).

A way to generate large numbers of T cells would be to amplify stem or progenitor cells and subsequently differentiate them into T cells. Human pluripotent stem cells (hPSCs) can self-renew and differentiate into any cell of the body, including hematopoietic cells. hPSCs are either human embryonic stem cells (hESCs) derived from blastocysts, or human induced pluripotent stem cells (hiPSCs) reprogramed from somatic cells (Thomson et al., 1998; Takahashi and Yamanaka, 2006; Takahashi et al., 2007). Since their derivation in 1998, hESCs have become a useful model for the study of human development or analysis of lineage and differentiation in vitro. In 2006, induced pluripotent stem cells (iPSCs) were obtained by reprograming mouse and human adult somatic cells using transduction of four factors essential for pluripotency. hiPSCs can be generated from patients with different diseases, therefore they can be used to obtain cells that carry genetic specificities and thus study the impact of this disease on development. Related to T lymphocytes, $\mathrm{T}$ cell clones with a desired antigenic specificity can be reprogramed into iPSC, which can be differentiated into an unlimited number of $\mathrm{T}$ lymphocytes preserving their given antigenic specificity (Kawamoto et al., 2018). Altogether, hiPSCs and hESCs are valuable tools for studying human development, disease modeling, drug screening and could provide an unlimited number of cells for regenerative medicine and cell therapy.

Some protocols for $\mathrm{T}$ cell differentiation are available (Timmermans et al., 2009; Mohtashami et al., 2010; Kennedy et al., 2012; Nishimura et al., 2013; Themeli et al., 2013; Sturgeon et al., 2014; Zhu et al., 2015). They rely on two steps: first, the differentiation of HSPCs from manque petit hPSCs, second, the differentiation of those progenitors into $\mathrm{T}$ cells. These protocols necessitate the use of hPSCs cultured on feeders, which limits the amount of $\mathrm{T}$ cells that can be subsequently generated. Moreover, these protocols are not standardized and the yield remains variable from one cell line to another. Therefore, better defined protocols are still needed.

There are several methods to differentiate hPSCs into hematopoietic progenitors: in co-culture with OP9 stromal cells (Holmes and Zúñiga-Pflücker, 2009; Ditadi and Sturgeon, 2016), in 2D (Salvagiotto et al., 2011; Slukvin, 2013) and 3D cultures through the formation of embryoid bodies (EBs) (Cerdan et al., 2007; Ng et al., 2008). These methods generally rely on induction of mesoderm through BMP signaling (Beddington and Robertson, 1999; Langdon and Mullins, 2011), followed by hemangiogenic induction by VEGF, SCF, FLT31, IL3, and
FGF2 (Ackermann et al., 2015) and after roughly a week of culture, the cells express CD34, a major marker of hematopoietic progenitors. The objective of this first step of differentiation is thus to obtain hematopoietic progenitors with a specific surface marker signature: $\mathrm{CD}_{4} 3^{+}, \mathrm{CD}_{4} 5^{+}, \mathrm{KDR}^{-}$.

Differentiation protocols aim to recapitulate the development of lymphocytes. Hence, the induction of lymphopoiesis relies on stimulation by SCF, FLT3l, IL7, and Notch signaling (Moore and Zlotnik, 1997; Radtke et al., 1999, 2004; Politikos et al., 2015). Differentiation effectiveness can be assessed by surface markers. The first expected event is that cells stop expressing CD34. The lymphopoiesis can then be followed by the subsequent expression of CD7, CD5 and finally the main markers CD4 and CD8.

In this study, we assessed parameters that would influence the robustness of hematopoietic and T-lineage cells differentiation from hPSCs. We used a protocol in two steps: (1) induction of hematopoietic differentiation through embryoid body (EB) formation in serum free medium and under two different predifferentiation culturing conditions (feeder or feeder-free); (2) directed differentiation of hPSC-derived multipotent HSPCs into T-lineage cells by co-culture with OP9-DLL1 or OP9-DLL4 bone marrow stromal cells.

We efficiently generated human $\mathrm{CD} 34^{+} \mathrm{CD} 45^{+} \mathrm{CD} 43^{ \pm} \mathrm{KDR}^{-}$ hHSPCs from hPSCs maintained in two different types of culture, a co-culture with mitotically-inactivated mouse embryonic fibroblast (MEF) (i.e., feeder) and a culture on Matrigel-coated plates (i.e., feeder-free). The use of feeder-free cultured hPSCs resulted in efficient hHSPC induction, with yields similar to feeder-cultured hPSCs. We subsequently differentiated hHSPCs into $\mathrm{CD}^{+} \mathrm{T}$ lineage progenitors efficiently, with no noticeable difference between OP9-DLL1 or OP9-DLL4 co-culture. Within the $\mathrm{T}$ lineage progenitor population, we detected $\mathrm{CD} 4{ }^{+} \mathrm{CD} 8^{+}$, $\mathrm{CD} 4^{+} \mathrm{CD} 8^{-}$and $\mathrm{CD} 4^{-} \mathrm{CD} 8^{+}$populations.

\section{MATERIALS AND EQUIPMENTS}

\section{Cell Lines}

- hES cells: hESC lines H1 (WA01, lot WB0111, male, $n=1$ ) and H9 (WA09, lot WB0090, female, $n=21$ ) were obtained from the WiCell Research Institute, under authorization RE13-004 from the French embryo research oversight committee, Agence de la Biomédecine.

- Transgene-free hiPS cells: 4 cell lines from male T-cell reprograming, T04.01A $(n=20)$, T04.01B $(n=6)$, T05.003 $(n=5)$ and T05.006 $(n=8)$ (Flippe et al., 2019). Two cell lines from male fibroblasts i.e., Lon71.019 $(n=9)$ (Gaignerie et al., 2018) and BJ1.B1 $(n=1)$ (Kilens et al., 2018). Four cell lines from female fibroblast reprograming i.e., Lon80.B2 ( $n=1)$ (Gaignerie et al., 2018), MiPS203.B3 $(n=1), \operatorname{MiPS} 209.003(n=5)$ and MiPS220.003 $(n=5)$ (Kilens et al., 2018).

All cell lines were generated in the iPSC core facility of the University of Nantes. 
- Mouse embryonic fibroblasts (MEFs) mitoticallyinactivated (produced in house from SWISS/SWISS mice).

- OP9-DLL1 or DLL4 mouse bone marrow stromal cell lines expressing the delta-like ligand of the Notch pathway (kindly provided by Dr. Juan-Carlos Zuniga-Pflucker, University of Toronto).

\section{Reagents}

- Matrigel (Corning Cat\# 354277).

- Gelatin solution, type B (Sigma Cat\# G1393).

- 0.5\% Trypsin-EDTA (Life Technologies Cat\# 25300-054).

- Dispase, 5 U/ml (StemCell Technologies Cat\# 07913).

- mTeSR1 (StemCell Technologies Cat\# 85850).

- DMEM F-12 (Life Technologies Cat\# 31330-038.

- DMEM, high glucose, GlutaMAX Supplement (Life Technologies Cat\# 61965026).

- $\alpha$-MEM (Life Technologies Cat\# 22561-021).

- Stempro-PRO-34 SFM + Supplement (Life Technologies Cat\# 10639-011).

- KnockOut ${ }^{\mathrm{TM}}$ Serum Replacement (KSR, Life Technologies Cat\# A31815-02).

- Fetal Bovine Serum (Hyclone Cat\# SV30160.03).

- GlutaMAX Supplement (Life Technologies Cat\# 35050038).

- Penicillin-Streptomycin, 10,000 U/ml (Life Technologies Cat\# 15140-122).

- Non-essential amino acids (NEAA; Life Technologies Cat\# 11140-035).

- 2-Mercaptoethanol, $50 \mathrm{mM}$ (Life Technologies Cat\# 31350-010).

- L-Ascorbic acid (Sigma Cat\# A7506).

- Y-27632 dihydrochloride (RockI; Axon Cat\# 1683).

- Sodium Pyruvate (Life Technologies Cat\# 11360-039).

- Phosphate Buffered Saline (PBS; Life Technologies Cat\#14190144).

- Recombinant cytokines - see Table 1

- Anti-human antibodies for flow cytometry - see Table 2

\section{Equipments}

- 6-Well tissue culture plates (Falcon).

- 6-Well low-adherence tissue culture plates (Corning).

- 6-cm culture dishes (Falcon).

- 5, 15, and $50 \mathrm{ml}$ sterile centrifuge tubes (Falcon).

TABLE 1 | Recombinant cytokines used for hPSCs culture and differentiation.

\begin{tabular}{lcc}
\hline Cytokines & Supplier & Catalog \# \\
\hline FGF2 & PeproTech & $100-18 B$ \\
BMP4 & R\&D Systems & $314-B P$ \\
VEGF121 & PeproTech & $100-20 A$ \\
SCF & PeproTech & $300-07$ \\
FLT3I & PeproTech & $300-19$ \\
IL3 & PeproTech & $200-03$ \\
IL7 & PeproTech & $200-07$
\end{tabular}

TABLE 2 | Antibodies used for analysis of differentiation cultures.

\begin{tabular}{lccccc}
\hline Antigens & Clones & Conjugate & Supplier & Catalog \# & Dilution \\
\hline CD34 & 581 & PE-Cy7 & BD Biosciences & 560710 & $1 / 30$ \\
CD43 & 1 G10 & APC & BD Biosciences & 560198 & $1 / 30$ \\
CD45 & 2D1 & APC-Cy7 & BD Biosciences & 557833 & $1 / 40$ \\
KDR & 89106 & PE & BD Biosciences & 560494 & $1 / 30$ \\
CD7 & M-T701 & PECF594 & BD Biosciences & 562541 & $1 / 25$ \\
CD5 & UCHT2 & BV711 & BD Biosciences & 563170 & $1 / 25$ \\
CD8 & SK1 & BV605 & BD Biosciences & 564116 & $1 / 25$ \\
CD4 & RPA-T4 & FITC & BD Biosciences & 555346 & $1 / 25$ \\
CD8b & 2ST8.5H7 & PE & BD Biosciences & 641057 & $1 / 25$ \\
CD56 & B159 & FITC & BD Biosciences & 562794 & $1 / 30$ \\
\hline
\end{tabular}

- 2, 5, 10, 25, and $50 \mathrm{ml}$ sterile serological pipets (Falcon).

- $0.22 \mu \mathrm{m}$ filtration system.

- Cell culture centrifuge.

- $5 \% \mathrm{CO}_{2}$ incubator set at $37^{\circ} \mathrm{C}$.

- Biosafety hood.

- Water bath set at $37^{\circ} \mathrm{C}$.

$-4^{\circ} \mathrm{C}$ refrigerator.

$-20^{\circ} \mathrm{C}$ freezer.

$-150^{\circ} \mathrm{C}$ freezer.

- FACS CANTO and FACS LSRII or equivalent.

- FlowJo software.

\section{Reagents Preparation Matrigel Solution}

Thaw matrigel at $4^{\circ} \mathrm{C}$ overnight. Place the bottle of Matrigel $(1 \mathrm{mg} / \mathrm{ml})$ and tubes for aliquots on ice and aliquot matrigel $250-500 \mu \mathrm{L}$ in cold tubes with cold tips. Store at $-80^{\circ} \mathrm{C}$.

For use, thaw the $250-500 \mu \mathrm{l}$ aliquot at $4^{\circ} \mathrm{C}$ overnight. Place the aliquot and a $50 \mathrm{ml}$ tube on ice and resuspend the matrigel at a final concentration of $0.01 \mathrm{mg} / \mathrm{ml}$ in cold DMEM-F12.

\section{$0.1 \%$ Gelatin Solution}

Prepare a solution of $0.1 \%$ gelatin in PBS $1 \mathrm{X}$ and filter it at $0.22 \mu \mathrm{m}$. Store at $4^{\circ} \mathrm{C}$.

\section{MEF Culture Medium}

Supplement DMEM with FBS to a final concentration of $10 \%$, add NEAA and sodium pyruvate to a final concentration of $1 \%$. Store at $4^{\circ} \mathrm{C}$.

\section{hPSC mTeSR1 Medium (Feeder-Free Culture)}

Prepare as per manufacturer's protocol. Aliquot in $50 \mathrm{ml}$ tubes, pipetting no more than $40 \mathrm{ml}$ per tube to allow for volume expansion upon freezing. Store at $-20^{\circ} \mathrm{C}$ for storage or store at $4^{\circ} \mathrm{C}$ for immediate use.

\section{hPSC-KSR Medium (Feeder Culture)}

Supplement DMEM-F12 with KSR serum to a final concentration of $20 \%$, add NEAA and Glutamax to a final concentration of $1 \%$ and add $50 \mu \mathrm{g} / \mathrm{ml}$ of 2-Mercaptoethanol. Divide into $50 \mathrm{ml}$ aliquots and store at $-20^{\circ} \mathrm{C}$ or store at $4^{\circ} \mathrm{C}$ for immediate use. Immediately prior to use, supplement with FGF2 to a final concentration of $10 \mathrm{ng} / \mathrm{ml}$. 


\section{EB Medium}

Prepare Stempro-PRO-34 SFM as per manufacturer's protocol and add $2 \mathrm{mM}$ of GlutaMAX Supplement. Divide into $40 \mathrm{ml}$ aliquots and store at $-20^{\circ} \mathrm{C}$.

Prepare EB medium extemporaneously: thaw an aliquot of Stempro-PRO-34-SFM and add $50 \mu \mathrm{g} / \mathrm{ml}$ of 2-Mercaptoethanol, $1 \%$ of NEAA and $50 \mu \mathrm{g} / \mathrm{ml} \mathrm{L}$-Ascorbic acid.

\section{OP9 Medium}

Supplement $\alpha$-MEM with $20 \%$ FBS and 2 mM GlutaMAX Supplement. Store at $4^{\circ} \mathrm{C}$.

\section{OP9 Differentiation Medium}

Supplement OP9 medium with $50 \mu \mathrm{g} / \mathrm{ml}$ 2-Mercaptoethanol, $1 \%$ of NEAA, $50 \mu \mathrm{g} / \mathrm{ml} \mathrm{L-Ascorbic} \mathrm{acid} \mathrm{and} 1 \%$ of PenicillinStreptomycin. Store at $4^{\circ} \mathrm{C}$.

\section{hESCs/hiPSCs CULTURE}

\section{Feeder-Free Condition}

(1) At least $4 \mathrm{~h}$ (we recommend overnight) before thawing hPSCs, coat 6-well plates with Matrigel and incubate at $37^{\circ} \mathrm{C}$.

(2) Add $5 \mathrm{ml}$ of $\mathrm{mTeSR} 1$ to $15 \mathrm{ml}$ tube.

(3) Thaw a cryovial of hPSCs (frozen in CryoStore CS10 according to the manufacturer's protocol, Stemcell Technologies) in a $37^{\circ} \mathrm{C}$ water bath.

(4) Add $1 \mathrm{ml}$ of mTeSR1 dropwise to the cryovial and transfer the cell solution into the $15 \mathrm{ml}$ tube containing $5 \mathrm{ml}$ of $\mathrm{mTeSR} 1$.

(5) Centrifuge at $160 \mathrm{~g} 5 \mathrm{~min}$.

(6) Gently resuspend cells in $1.5 \mathrm{ml}$ of mTeSR $1+10 \mu \mathrm{g} / \mathrm{ml}$ Y27632. Transfer $1 / 3 \mathrm{rd}(500 \mu \mathrm{l})$ of the cells in a well containing $1 \mathrm{ml}$ of $\mathrm{mTeSR} 1+10 \mu \mathrm{g} / \mathrm{ml} \mathrm{Y27632,} \mathrm{the}$ other $2 / 3 \mathrm{rd}(1 \mathrm{ml})$ in a well containing $500 \mu \mathrm{l}$ of $\mathrm{mTeSR} 1+10 \mu \mathrm{g} / \mathrm{ml}$ Y27632.

(7) Change mTeSR1 daily until hPSC are $70-80 \%$ confluent.

(8) At least $4 \mathrm{~h}$ (we recommend overnight) before passing hPSCs, coat new 6-well plates with Matrigel and incubate at $37^{\circ} \mathrm{C}$.

(9) Remove mTeSR1, wash with $1 \mathrm{ml}$ of PBS $1 \mathrm{X}$ and add $1 \mathrm{ml}$ of StemMACS passaging solution XF for $3 \mathrm{~min}$ at room temperature. Aspirate and add $1 \mathrm{ml}$ of mTeSR1. Scrape cells back and forth in two directions in the well with $200 \mu \mathrm{l}$ tips.

NB: Be careful with the timing of incubation with the passaging solution. You might have to test multiple timings depending on your tissue culture practices. This step generates clumps of hPSCs that should be around $200 \mu \mathrm{m}$ in size.

(10) Take the chosen volume of cell solution and add into a new well containing $1.5 \mathrm{ml}$ of $\mathrm{mTeSR} 1$. Be careful to properly homogenize the cells and place at $37^{\circ} \mathrm{C}$ under $5 \% \mathrm{CO}_{2}$.

NB: The passaging ratio of hPSCs can vary from line-to-line, is very dependent of the lab and the manipulator. Usually for us, hPSCs are passed every 5-6 days at a ratio of $1 / 10$.

\section{Feeder Condition}

(1) At least $30 \mathrm{~min}$ before thawing mitotically-inactivated MEFs (Supplementary Material), coat $6 \mathrm{~cm}$ culture dishes with $1.5 \mathrm{ml}$ of gelatin.

(2) Thaw mitotically-inactivated MEFs (frozen in $80 \%$ FBS and $80 \%$ Dimethyl Sulfoxide: DMSO) in a $37^{\circ} \mathrm{C}$ water bath. Add $1 \mathrm{ml}$ of MEF medium dropwise to the vial and add the cell solution into the $50 \mathrm{ml}$ tube containing $5 \mathrm{ml}$.

(3) Centrifuge at $200 \mathrm{~g}$ for $5 \mathrm{~min}$.

(4) Resuspend in $10 \mathrm{ml}$ of MEF medium and count the cells. Aspirate the gelatin and plate $2.5 \mathrm{ml}$ of MEF solution into each $6-\mathrm{cm}$ culture dish for a final density of $4.2 \times 10^{5}$ cells per dish. Be careful to homogenize the cells well and place at $37^{\circ} \mathrm{C}$ under $5 \% \mathrm{CO}_{2}$ overnight.

(5) The following day, thaw a cryovial of hPSCs in a $37^{\circ} \mathrm{C}$ water bath.

(6) Add $5 \mathrm{ml}$ of KSR medium in a $15 \mathrm{ml}$ tube. Add $1 \mathrm{ml}$ of KSR medium dropwise to the vial and add the cell solution into the $15 \mathrm{ml}$ tube containing $5 \mathrm{ml}$ of KSR medium.

(7) Centrifuge at $160 \mathrm{~g}$ for $5 \mathrm{~min}$.

(8) Gently resuspend in $3 \mathrm{ml}$ of $\mathrm{KSR}$ medium $+10 \mathrm{ng} / \mathrm{ml}$ FGF2 + $20 \mu \mathrm{g} / \mathrm{ml} \mathrm{Y27632.} \mathrm{Remove} \mathrm{the} \mathrm{gelatin} \mathrm{from} \mathrm{the}$ dish and add cell solution in the first dish at a ratio of $1 / 3$ and a final volume of $3 \mathrm{ml}$. The second dish is complete at a ratio of $2 / 3$ and a final volume of $3 \mathrm{ml}$. Be careful to homogenize the cells well and place at $37^{\circ} \mathrm{C}$ under $5 \% \mathrm{CO}_{2}$.

(9) Every day, replace the KSR medium $+10 \mathrm{ng} / \mathrm{ml} \mathrm{FGF2} \mathrm{until}$ hPSC are $70-80 \%$ confluent.

(10) A day before the passage, MEFs are prepared as described in the section "Materials and Equipments, hESCs/hiPSCs Culture, Feeder Condition (1-3).”

(11) The day of passage, cut colonies in a grid pattern (about $200 \mu \mathrm{m}$ ) with a needle under a magnifying glass. Collect the pieces of colonies with a pipette of $200 \mu \mathrm{l}$ and transfer about 20 colonies in a new $6-\mathrm{cm}$ dish containing already $2.5 \mathrm{ml}$ of KSR medium $+10 \mathrm{ng} / \mathrm{ml} \mathrm{FGF2}$. Be careful to homogenize the cells well and place at $37{ }^{\circ} \mathrm{C}$ under $5 \%$ $\mathrm{CO}_{2}$.

NB: The passaging ratio of hPSCs can vary from line-to-line, it is very dependent of the lab and the manipulator. Usually for us, hPSCs are passed every 6-7 days at a ratio of $1 / 4$.

\section{Embryoid Bodies Formation \\ Feeder-Free Condition}

(1) 5-6 days before starting EB formation, pass the hPSCs as described in the section "Materials and Equipments, hESCs/hiPSCs Culture, Feeder-Free Condition (8-10)."

(2) Day - 1: Start the process when the cells are $70 \%$ confluent. Remove mTeSR1, wash with $1 \mathrm{ml}$ of PBS and add $1 \mathrm{ml}$ of StemMACS passaging solution XF for $3 \mathrm{~min}$ at room temperature. Very gently remove and wash with $1 \mathrm{ml}$ of $\alpha$-MEM. Add $1 \mathrm{ml}$ of mTeSR 1 and scrape cells back and forth in two directions of the well with $200 \mu \mathrm{L}$ tips.

NB: For this step the generated clumps of hPSCs should be bigger than for a simple passage around $300-350 \mu \mathrm{m}$ in size. 
(3) Very carefully transfer the cell clumps with a $5 \mathrm{ml}$ pipette into a low binding plate containing already $1 \mathrm{ml}$ of $\mathrm{mTeSR} 1+20 \mu \mathrm{g} / \mathrm{ml} \mathrm{Y} 27632$.

NB: Generally, for each 6-well matrigel-coated plate containing hPSCs, one 6-well low binding plate for differentiation can be used.

(4) Homogenize the cells and place at $37{ }^{\circ} \mathrm{C}$ under $5 \% \mathrm{CO}_{2}$ for no more than $18 \mathrm{~h}$.

NB: Be careful, the Y27632 exposure time is really important for this step. If the exposure time exceeds $18 \mathrm{~h}$, the embryoid bodies tend to disintegrate.

(5) Day 0: Collect EBs very gently with a $5 \mathrm{ml}$ pipette into a $15 \mathrm{ml}$ tube (1 tube for 1 well). Put $1 \mathrm{ml}$ of "Day 0" EB medium (Table 3) into the well to prevent it from drying. Wait a few minutes to let the EBs sediment at the bottom of the tube and remove the supernatant. Gently resuspend the EBs in the "Day 0" EB medium and very carefully transfer into the well already containing $1 \mathrm{ml}$ of medium. Place the plate at $37^{\circ} \mathrm{C}$ under $5 \% \mathrm{CO}_{2}$.

(6) NB: $24 \mathrm{~h}$ after the addition of BMP4 media, up to $20 \%$ of EBs collapsed due to the switch of medium from mTeSR1 to EB medium. This collapse might be evaluated by observation with phase contrast microscopes.

(7) Day 1: repeat the step (5) with "Day 1" EBs medium (Table 3).

(8) Idem for days 3, 5, and 7 (Table 3).

(9) Keep the cells until day 9 to have Hematopoietic Stem Cells.

\section{Feeder Condition}

(1) Pass the hPSCs as described in the section "Materials and Equipments, hESCs/hiPSCs Culture, Feeder Condition (911)" 6-7 days before starting EB formation.

(2) Day 0: start the process when the cells are $70 \%$ confluent. Remove KSR medium, wash with $1 \mathrm{ml}$ of PBS $1 \mathrm{X}$ and add $1.5 \mathrm{ml}$ of dispase $(1 \mathrm{U} / \mathrm{ml})$ for $10 \mathrm{~min}$ at $37^{\circ} \mathrm{C}$. With a $5 \mathrm{ml}$ pipette, add $2 \mathrm{ml}$ of DMEM-F12 and flush the colonies no more than 3 times. Collect the clumps and put them into a $15 \mathrm{ml}$ tube (1 tube for 1 dish). Proceed identically until there are no more colonies in the dish.

(3) Centrifuge at $160 \mathrm{~g}$ for $5 \mathrm{~min}$.

(4) Resuspend the clumps with $5 \mathrm{ml}$ DMEM-F12 and centrifuge again at $160 \mathrm{~g}$ for $5 \mathrm{~min}$.

TABLE 3 | EB complete medium formulation for hematopoietic cell induction.

\begin{tabular}{lcccccc}
\hline EBs Medium & $\begin{array}{c}\text { BMP4 } \\
\text { (ng/ml) }\end{array}$ & $\begin{array}{c}\text { FGF2 } \\
\text { (ng/ml) }\end{array}$ & $\begin{array}{c}\text { VEGF } \\
\text { (ng/ml) }\end{array}$ & $\begin{array}{c}\text { SCF } \\
\text { (ng/ml) }\end{array}$ & $\begin{array}{c}\text { FLT3l } \\
\text { (ng/ml) }\end{array}$ & IL3 (ng/ml) \\
\hline Day 0 & 30 & - & - & - & - & - \\
Day 1 & 30 & 5 & - & - & - & - \\
Day 3 & - & 5 & 20 & 100 & 20 & 20 \\
Day 5 & - & 5 & 20 & 100 & 20 & 20 \\
Day 7 & - & & 20 & 100 & 20 & 20
\end{tabular}

(5) Resuspend the pellet of clumps very gently into $2 \mathrm{ml}$ of "Day 0" EB medium and transfer the cells very carefully with a $5 \mathrm{ml}$ pipette into a low binding plate. Homogenize the cells and place at $37^{\circ} \mathrm{C}$ under $5 \% \mathrm{CO}_{2}$.

NB: Typically, colonies from two 6-cm dishes go into one well of a 6-well low binding plate in $2 \mathrm{ml}$ of EB medium.

(6) Day 1: Collect EBs very gently with a $5 \mathrm{ml}$ pipette in a $15 \mathrm{ml}$ tube ( 1 tube for 1 well). Put $1 \mathrm{ml}$ of "Day 1" EBs medium (Table 3) into the well to prevent it from drying. Wait a few minutes to let the EBs sediment at the bottom of the tube and remove the supernatant. Gently resuspend the EBs in the "Day 1" EB medium and very carefully transfer into the well already containing $1 \mathrm{ml}$ of medium. Place the plate at $37^{\circ} \mathrm{C}$ under $5 \% \mathrm{CO}_{2}$.

(7) Day 3: repeat the step (6) with "Day 3" EBs medium (Table 3).

(8) Same for day 5 and day 7 (Table 3).

(9) Keep the cells until day 9 to obtain Hematopoietic Stem Cells.

\section{Hematopoietic Progenitor Analysis}

(1) At days 7 and 9, collect one 6-well low binding plate of EBs with a $5 \mathrm{ml}$ pipette and transfer them into a $15 \mathrm{ml}$ tube. Rinse the well with $2 \mathrm{ml}$ of PBS $1 X$.

NB: One 6-well low binding plate in one $15 \mathrm{ml}$ tube.

(2) Centrifuge for $5 \mathrm{~min}$ at $450 \mathrm{~g}$.

(3) Remove the supernatant and resuspend in $1 \mathrm{ml}$ of Accutase. Incubate $15 \mathrm{~min}$ at $37^{\circ} \mathrm{C}$.

(4) Pipette up and down with $1 \mathrm{ml}$ tips to break the EBs.

NB 1: This step requires about $5 \mathrm{~min}$ per tube to sufficiently break the EBs.

NB 2: If the EBs are not yet broken, do an extra 5-10 min at $37^{\circ} \mathrm{C}$.

(5) Add $5 \mathrm{ml}$ of PBS $1 \mathrm{X}$ and centrifuge $7 \mathrm{~min}$ at $450 \mathrm{~g}$.

(6) Resuspend the cells in $1 \mathrm{ml}$ of FACS buffer and pass them through a $60 \mu \mathrm{m}$ cell filter.

(7) Wash the cells with FACS buffer by centrifugation at $450 \mathrm{~g}$ for $7 \mathrm{~min}$. Keep 1/3 of the cells from each condition and use them for the unstained and isotype control conditions. Incubate the cells with anti-hCD34, anti-hCD43, antihCD45 and anti-hKDR antibodies in FACS buffer for 30 min at $4^{\circ} \mathrm{C}$ in the dark (Table 2).

(8) Wash the cells twice with FACS buffer and resuspend them in PBS 1X + DAPI.

(9) Analyze the cells using flow cytometry.

\section{LYMPHOCYTE DIFFERENTIATION}

\section{OP9-DLL1 or OP9-DLL4 Culture}

\section{Thawing}

(1) At least 30 min before thawing OP9-DLL1 or DLL4 cells, coat two $10-\mathrm{cm}$ dishes with $5 \mathrm{ml}$ of $0.1 \%$ gelatin. 
(2) Add $10 \mathrm{ml}$ of OP9 medium to a $50 \mathrm{ml}$ tube.

(3) Thaw a cryovial of OP9-DLL1 or OP9-DLL4 (frozen in $80 \%$ FBS and $20 \%$ DMSO) cells quickly in a $37^{\circ} \mathrm{C}$ water bath.

(4) Add $1 \mathrm{ml}$ of OP9 medium dropwise to the vial and add the cell solution to the $50 \mathrm{ml}$ tube containing $10 \mathrm{ml}$ of OP9 medium.

(5) Centrifuge at $200 \mathrm{~g}$ for $5 \mathrm{~min}$.

(6) Resuspend the cells in $3 \mathrm{ml}$ of OP9 medium.

(7) Aspirate the gelatin. Add in one $10-\mathrm{cm}$ dish, $8 \mathrm{ml}$ of OP9 medium, and $9 \mathrm{ml}$ of OP9 medium in the other.

(8) Transfer the cell solution into the two $10-\mathrm{cm}$ dishes to a final volume of $12 \mathrm{ml}$ per dish.

(9) Place the dishes at $37^{\circ} \mathrm{C}$ under $5 \% \mathrm{CO}_{2}$.

\section{Maintaining}

(1) The day of passage, remove the medium and wash with $5 \mathrm{ml}$ of PBS $1 \mathrm{X}$.

NB: Pass the cells at $70 \%$ confluency.

(2) Add $2 \mathrm{ml}$ of $0.25 \%$ trypsin solution and incubate $5 \mathrm{~min}$ at $37^{\circ} \mathrm{C}$.

(3) Add $10 \mathrm{ml}$ of OP9 medium and disaggregate the cells from the dish by pipetting them up and down.

(4) Transfer the cells to a $50 \mathrm{ml}$ tube and centrifuge at $200 \mathrm{~g}$ for $5 \mathrm{~min}$.

(5) Resuspend in $5 \mathrm{ml}$ of OP9 medium and transfer $1 \mathrm{ml}$ of cell solution into $10-\mathrm{cm}$ dish previously coated with $0.1 \%$ gelatin and containing $9 \mathrm{ml}$ of OP9 medium.

NB 1: Keep the split ratio at 1-to-5 for passaging the cells every 3-4 days. Passage the cells before they reach $80 \%$ confluency and do not keep them in culture for more than 5-7 weeks.

NB 2: DLL1 and DLL4 ligand expression by the OP9 cells can be monitored on a regular basis by flow cytometry to check that there is no loss of ligand expression due to culture (Supplementary Figure 1 and Supplementary Table 1)

\section{Generation of Lymphoid Progenitors}

Preparation of OP9-DLL1 or OP9-DLL4 for Co-culture

(1) $24 \mathrm{~h}$ before starting the co-culture with OP9-DLL1 or OP9DLL4 cells, coat 12 -well plates with $0.1 \%$ gelatin for $30 \mathrm{~min}$.

NB: OP9-DLL1 or OP9-DLL4 cells need to be at $70 \%$ confluency at day 8 .

(2) Prepare the OP9-DLL1 or OP9-DLL4 cells as in step "Maintaining" (1-5).

(3) Resuspend the cells in $5 \mathrm{ml}$ of OP9 medium. Count the number of cells and seed $3.5 \times 10^{4}$ cells per 12 -well plate.

(4) Be careful to homogenize the cells well and place them at $37^{\circ} \mathrm{C}$ under $5 \% \mathrm{CO}_{2}$.

\section{Dissociation of EBs to Recover HSPCs}

(1) At day 9, collect one 6-well low binding plate of EBs with a $5 \mathrm{ml}$ pipette and transfer them to a $15 \mathrm{ml}$ tube. Rinse the well with $2 \mathrm{ml}$ of $\alpha$-MEM.

NB: One 6-well low binding plate in one $15 \mathrm{ml}$ tube.
(2) Centrifuge for $5 \mathrm{~min}$ at $450 \mathrm{~g}$.

(3) Remove the supernatant and resuspend in $1 \mathrm{ml}$ of Accutase. Incubate $15 \mathrm{~min}$ at $37^{\circ} \mathrm{C}$.

(4) Pipette up and down with $1 \mathrm{ml}$ tips to break the EBs.

NB 1: This step requires about 5 min per tube to sufficiently break the EBs.

NB 2: If the EBs are not yet broken, it is possible to incubate an extra $5-10 \mathrm{~min}$ in $37^{\circ} \mathrm{C}$.

(5) Add $5 \mathrm{ml}$ of $\alpha$-MEM and centrifuge $7 \mathrm{~min}$ at $450 \mathrm{~g}$.

(6) Resuspend the HSPCs in $1 \mathrm{ml}$ OP9 differentiation medium + hSCF $(10 \mathrm{ng} / \mathrm{ml})$, hFlt3L $(5 \mathrm{ng} / \mathrm{ml})$ and hIL-7 (5 ng/ml).

\section{Co-culture With OP9-DLL1 or OP9-DLL4}

(1) Remove the medium in OP9-DLL1 or OP9-DLL4 12-well plates and add $1 \mathrm{ml}$ of OP9 differentiation medium + hSCF (10 ng/ml), hFlt3L (5 ng/ml) and hIL-7 (5 ng/ml).

(2) Add the $1 \mathrm{ml}$ of HSPC solution into a 12-well plate of OP9DLL1 or OP9-DLL4 and place the plate at $37^{\circ} \mathrm{C}$ under $5 \%$ $\mathrm{CO}_{2}$.

NB 1: One 6-well low binding of EBs in one 12-well plate coated with OP9-DLL1 or OP9-DLL4 cells.

NB 2: the cells are in a final volume of $2 \mathrm{ml} \mathrm{OP} 9$ differentiation medium plus hSCF $(10 \mathrm{ng} / \mathrm{ml})$, hFlt3L $(5 \mathrm{ng} / \mathrm{ml})$ and hIL$7(5 \mathrm{ng} / \mathrm{ml})$.

(3) Every 2 days, replace half of the medium. Remove $1 \mathrm{ml}$ of medium from each well by leaning against the edge of the well with a $1 \mathrm{ml}$ tip.

(4) Add $1 \mathrm{ml}$ of OP9 differentiation medium + hSCF (20 $\mathrm{ng} / \mathrm{ml})$, hFlt3L (10 ng/ml) and hIL-7 (10 ng/ml).

NB: The final concentration of cytokines in $2 \mathrm{ml}$ of OP9 differentiation medium is: hSCF (10 ng/ml), hFlt $3 \mathrm{~L}(5 \mathrm{ng} / \mathrm{ml})$ and hIL-7 (5 ng/ml).

(5) Every 5 days, the cells are passed on new feeder layers of OP9-DLL1 or OP9-DLL4 cells.

(6) Prepare OP9-DLL1 or OP9-DLL4 cells as in step (1-4).

(7) To harvest the semi adherent hematopoietic cells, use the medium in the well and wash the cells very gently to keep the feeder layer intact.

NB 1: One $15 \mathrm{ml}$ tube per well.

NB 2: If the feeder layer is broken in small clumps, just passage everything to a new layer.

NB 3: If the feeder layer comes off completely, try to recover the free cells but do not transfer the feeder layer mass.

(8) Transfer the cells in a $15 \mathrm{ml}$ tube and rinse 2 times with $1 \mathrm{ml}$ of $\alpha$-MEM to recover all the cells.

(9) Centrifuge $10 \mathrm{~min}$ at $450 \mathrm{~g}$.

(10) Resuspend the pellet in $1 \mathrm{ml}$ of OP9 differentiation medium + hSCF $(10 \mathrm{ng} / \mathrm{ml})$, hFlt3L $(5 \mathrm{ng} / \mathrm{ml})$ and hIL$7(5 \mathrm{ng} / \mathrm{ml})$.

(11) Aspirate the OP9 medium from 12-well plates and add $1 \mathrm{ml}$ onto OP9-DLL1 or OP9-DLL4 cells of OP9 differentiation 
medium with hSCF (10 ng/ml), hFlt3L (5 ng/ml) and hIL$7(5 \mathrm{ng} / \mathrm{ml})$.

(12) Add the cell solution into OP9-DLL1 or OP9-DLL4 cells.

NB: The final volume is $2 \mathrm{ml}$ per well.

\section{Flow Cytometry Analysis}

(1) Resuspend the cells in $1 \mathrm{ml}$ of FACS buffer and pass them through a $60 \mu \mathrm{m}$ cell filter.

(2) Wash the cells with FACS buffer and centrifuge at $450 \mathrm{~g}$ for $7 \mathrm{~min}$. Keep 1/3 of the cells form each condition and use them for unstained and isotype control conditions. Incubate the cells with anti-hCD34, anti-hCD43, antihCD45 and anti-hKDR antibodies in FACS buffer for $30 \mathrm{~min}$ at $4^{\circ} \mathrm{C}$ in the dark (Table 2).

(3) Wash the cells twice with FACS buffer and resuspend them in PBS 1X + DAPI.

(4) Analyze the cells via flow cytometry.

\section{RESULTS}

Our objective was to design a protocol that would efficiently enable the differentiation of hPSC cultured in feeder-free conditions into hHSPCs (Figure 1A). In our hands, the differentiation of hPSCs into hHSPCs was more efficient with EBs in 3D culture, therefore we rapidly dropped the 2D hHSPCs induction protocol. Indeed, the 2D protocol was yielding less than $5 \%$ hHSPCs, was expensive and required sorting or magnetic separation of CD34 positive cells.

We evaluated the efficiency of EB formation and HSPC generation from hPSCs cultured on feeder or feeder-free conditions. Of note, we differentiated EBs without serum as it may contain inhibitory factors and it is difficult to troubleshoot the variability of serum batches. To monitor the efficiency of the differentiation, an informative readout was the morphology of EBs in both conditions. EBs were formed within $24 \mathrm{~h}$ after hPSC dissociation. The first 3 days (D0- D3), EBs grew slightly in size reaching 450-500 $\mu \mathrm{m}$ (Figure 1B). Between D3 and D5, EBs grew significantly and we observed protuberances coming out of the initially round shape of the EBs. Between D7 and D9, both EBs and protuberances grew significantly. Overall, the volume of EBs could triple in the course of the 9 days differentiation protocol (Figure 1B). Prior to any phenotypic or genotypic analysis, the morphology of the EBs, their growth and the appearance of protuberances ensured a good induction of the hematopoietic differentiation. Overall, EB formation from hPSCs cultured in feeder or feeder-free conditions behaved similarly.

At D7 and D9, we monitored the hematopoietic differentiation by flow cytometry to show the acquisition of key markers of the hematopoietic lineage. We analyzed the expression of 4 markers to identify hematopoietic stem cells: CD34 as the major human hematopoietic stem cells (hHSCs) marker (Berenson et al., 1988), CD43 as an early marker of hematopoiesis (Vodyanik et al., 2006), CD45 as the most common marker for hematopoietic cells (Vodyanik et al., 2006) and KDR as an endothelial cell marker also commonly used to identify hemangioblasts (Kennedy et al., 2012; Sturgeon et al., 2014). At D7, CD34 marker expression averaged $27 \pm 12.1 \%$ and at $\mathrm{D} 9$, this expression reached $37 \pm 13.7 \%$ of the total culture in both feeder and feeder-free culture conditions (tested on 12 cell lines). Between D7 and D9, we observed the acquisition of the $\mathrm{CD} 43$ marker in $\mathrm{CD} 34^{+}$ cells. There was an average of 3 and $13 \% \mathrm{CD} 34^{+} \mathrm{CD} 43^{+}$cells at D7 and D9, respectively (Figures 2A-C). However, we cannot exclude that part of $\mathrm{CD} 43^{+}$cells from D7 may proliferate and contribute to this increase of $\mathrm{CD} 43^{+}$cells between $\mathrm{D} 7$ and D9. Of note, weak expression of KDR, an endothelium marker (Sturgeon et al., 2014), was detected at D7 only in cells cultured on feeder cells prior to differentiation. At D7, in the feeder condition, $\mathrm{CD} 34^{+}$cells had little expression of the CD45 marker, while in contrast, in the feeder-free condition, the $\mathrm{CD} 34^{+} \mathrm{CD} 43^{-}$cells already expressed CD45 (Figure 2B). In the feeder condition, the expression of KDR decreased while the expression of CD45 was increased in $\mathrm{CD} 34^{+} \mathrm{CD} 43^{+}$cells between D7 and D9. Feeder-free cultured hPSCs therefore seem to differentiate slightly faster than feeder culture ones. After 9 days of differentiation of hPSCs into EBs, the differentiated cells had identical phenotypes regardless of whether they came from feeder or feeder-free systems: there was an average of $37 \pm 13.7 \% \mathrm{CD} 34^{+}$cells in the total population, all of them expressing CD45 (Figures 2B,C).

After establishing robust hematopoietic induction of hPSC cultured in feeder-free conditions, we sought to optimize lymphopoiesis induction. To do so, we assessed co-culture of hHSPCs differentiated from hPSCs for 9 days with the OP9 line of mouse bone marrow stromal cells constitutively expressing DLL1 or DLL4. Both DLL1 and DLL4 have been used in lymphopoiesis protocols with human PSCs (La Motte-Mohs et al., 2005; Mohtashami et al., 2013; Nishimura et al., 2013; Themeli et al., 2013), but few studies have compared the two cell types. EBs were dissociated at day 9 using accutase and the cell suspension, consisting of individualized cells and some small clumps, was seeded on top of OP9-DLL1 or OP9-DLL4 cells (Figure 1C). Between D10 and D13, some individualized cells were detached from the small clumps. By day 14, we generally observed small rounded cells, often distributed in clusters (Figure 1B). We monitored progression toward the $\mathrm{T}$ lymphocyte fate by flow cytometry analysis using the following surface markers: CD7 as an early marker of the T-cell lineage (Lobach et al., 1985), CD8 and CD4 as commonly used to identify the two main types of T cells (Miceli and Parnes, 1991). At least 40\% of cells cocultured on OP9-DLL1 or OP9-DLL4 were CD7 positive by day 20 (Figures $3 \mathbf{A}-\mathbf{C}$ ). This was not modulated by OP9-DLL1 or OP9-DLL4 co-culture. We observed a trend for the feeder condition to be less potent at inducing CD7 expression than feeder-free culture of hPSCs prior to differentiation $(36.4 \pm 7.2 \%$ vs. $53.8 \pm 21.4 \%$, respectively). At day 20 , about $5 \%$ of $\mathrm{CD}^{+}$ cells expressed the CD4 marker whereas a higher proportion expressed the CD8 marker (15\%) and only a small proportion (1$2 \%$ ) were double positive $\mathrm{CD} 4^{+} \mathrm{CD}^{+}$in feeder-free condition (Figure 2C). At least $70 \%$ of the cells were $\mathrm{CD}^{+}$by day 30 and $5-10 \%$ of cells were $\mathrm{CD} 4^{+} \mathrm{CD} 8^{+}$(Figures $2 \mathrm{~B}, \mathrm{C}$ ). These $\mathrm{CD}^{+} \mathrm{CD}^{+} \mathrm{CD}^{+}$cells were progenitors of the $\mathrm{T}$ lineage. The efficiency of differentiation at day 30 was not affected either by the OP9-DLL1 or OP9-DLL4, or by the feeder/feeder-free culture of hPSCs prior to differentiation. Moreover, we did 


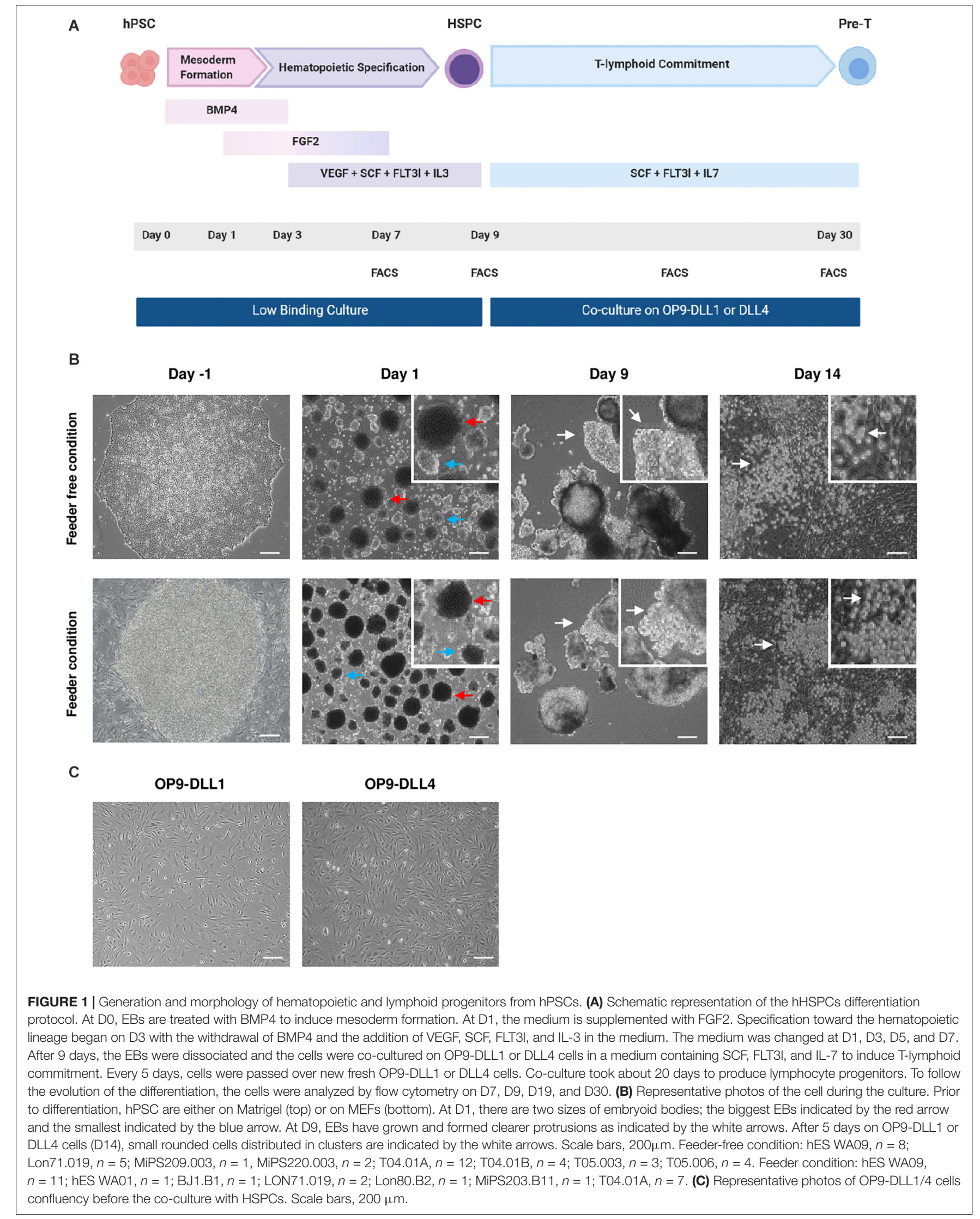


A

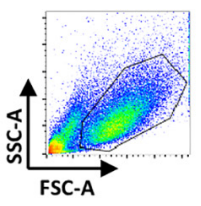

B

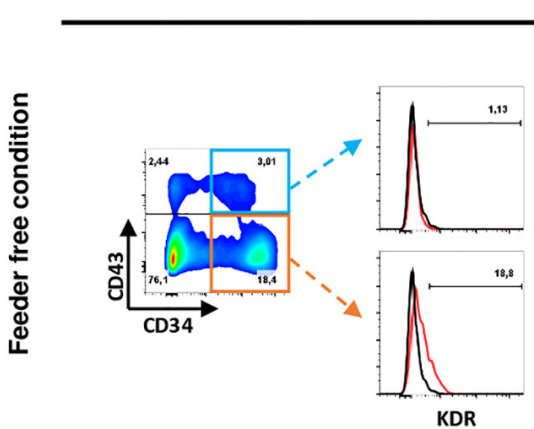

EB day 7
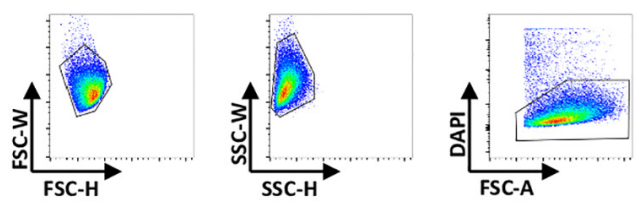
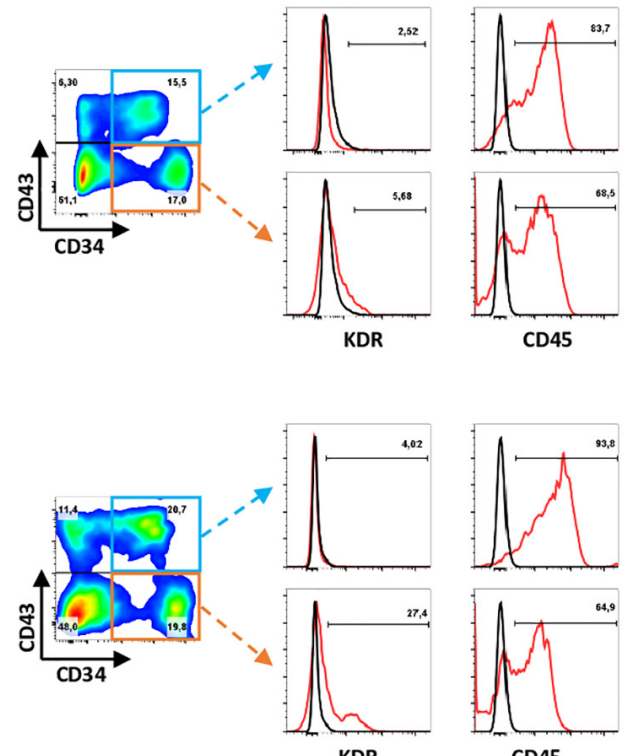

CD45
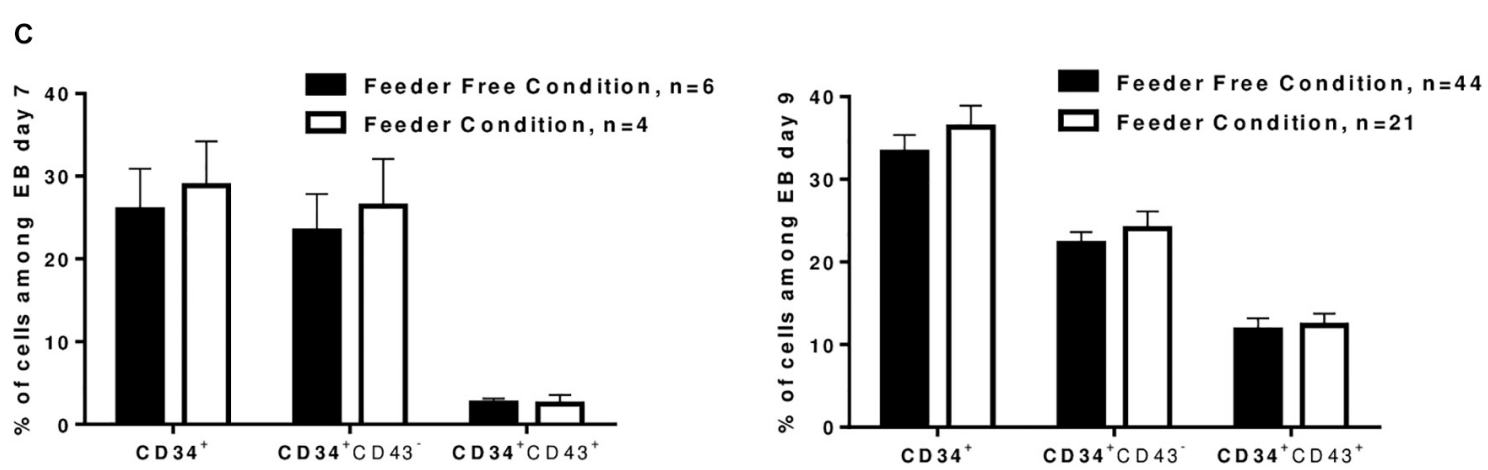

FIGURE 2 | Induction of HSPCs. (A) Representative gating strategy for differentiated cells analysis by flow cytometry: differentiated cells were selected on morphology after exclusion of doublets and dead cells (DAPI). (B) Flow-cytometry analysis of differentiating cells at D7 (left) and D9 (right) in EB culture from hPSC in feeder-free condition (top) and in feeder condition (bottom). Representative dot plot of CD34 and CD43 co-staining on living cells is shown on the left. The expression of KDR and CD45 in $\mathrm{CD} 34^{+}{ }^{\mathrm{CD}} 43^{+}$(top) or $\mathrm{CD} 34^{+} \mathrm{CD} 43^{-}$(bottom) cells is shown on the right. Red line represents cells stained with a fluorescent antibody and black line represents unstained cells. (C) Percent of total cells from EBs day 7 (left) and day 9 (right) expressing the markers, Mean \pm SEM are represented.

not observe any influence of the source of cells: hESCs or hiPSC reprogramed from fibroblast, lymphocytes (10 hiPSC and $2 \mathrm{hESC}$ lines were used). To further demonstrate that these progenitors are bona fide DP T cells, we further differentiated them into $\mathrm{CD} 8 \alpha^{+} \mathrm{CD} 8 \beta^{+}$cells and $\mathrm{CD} 4^{+} \mathrm{CD} 8^{-}$cells (SP) $\mathrm{T}$ cells in the feeder condition on OP9-DLL1 (Figure 3D). In addition, we show the presence of $\mathrm{CD}^{+} 6^{+}$cells at day 35 . Digital gene RNA sequencing (DGE-RNAseq) data from D25 cells compared to $\mathrm{CD} 8{ }^{+} \mathrm{CD} 4^{+}$thymus cells demonstrated that
T cells on OP9-DLL1 and DLL4 feeder free and OP9-DLL1 feeder cells expressed similar levels of lymphoid lineage genes and cytotoxicity mediators than $\mathrm{CD} 8^{+} \mathrm{CD} 4^{+}$cells from thymus (Supplementary Figure 2). Indeed, cells at day 25 express key genes for lymphopoiesis such as GATA3, IL7R, BCL11b, CD25, as well as PTCRA, a gene involved in the formation of the preTCR complex and all chains of CD3. In addition, we observed the expression of cytotoxic mediators such as GNLY, GZMB, TNFSF10, and TYROBP. This altogether demonstrates that our 
A
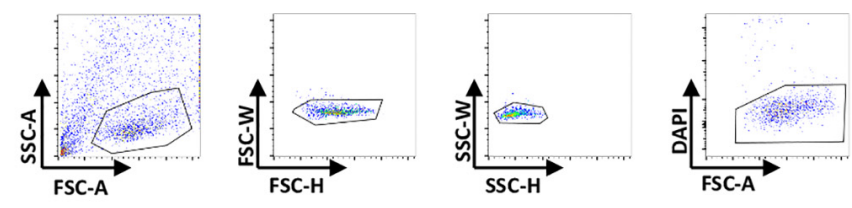

B

Day 20

Day 30
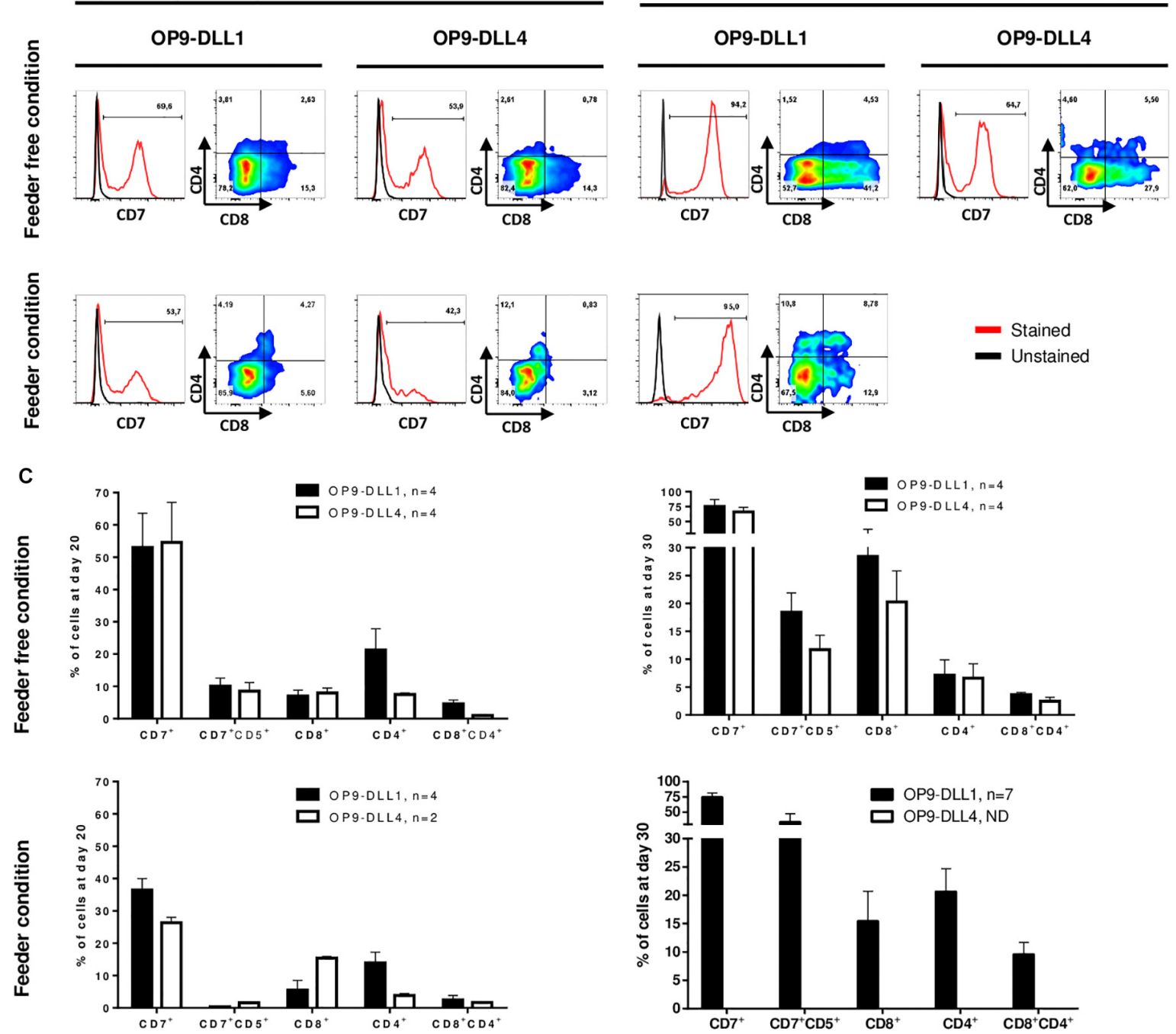

D

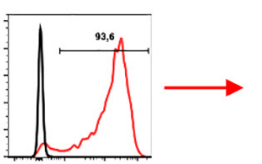

CD7

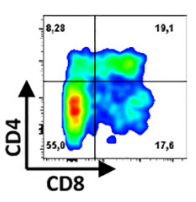

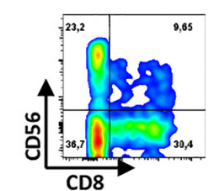

FIGURE 3 | T cell progenitors' differentiation is neither dependent on hPSCs culture conditions nor lymphopoietic induction by OP9-DLL1 or DLL4.

(A) Representative gating strategy for differentiated cells analysis by flow cytometry: differentiated cells were selected on morphology after exclusion of doublets and dead cells (DAPI). (B) Representative histogram of CD7 expression in living cells (excluding OP9) on OP9-DLL1 (left) or OP9-DLL4 (right) from feeder-free condition (top) and feeder condition (bottom) at day 20 and day 30. Red line represents cells stained with a fluorescent antibody and black line represents unstained cells. The expression of CD8 and CD4 among CD7+ cells is shown in dot plot. (C) Percent of total living cells (excluding OP9) at day 20 and day 30 in OP9-DLL1 or in OP9-DLL4 expression the markers, Mean \pm SEM are represented. (D) Representative histogram of CD7 expression in living cells (excluding OP9) on OP9-DLL1 from feeder condition at day 35 . Red line represents cells stained with a fluorescent antibody and black line represents unstained cells. The expression of CD8 $\alpha$, $\mathrm{CD} 8 \beta, \mathrm{CD} 4$, and CD56 among CD7 ${ }^{+}$cells is shown in dot plot. 
hHSPCs derived from EB differentiation from hPSCs were able to differentiate to $\mathrm{T}$ cell progenitors.

To assess the value of our protocol, we compared the time necessary for each setup (Figure 4). Expansion of hPSCs in feeder-free culture conditions is 3 weeks faster than in feeder culture conditions, prior to differentiation. Indeed, with feeders, from thawing to EB formation required about 35 days to have 12 dishes ready. In the feeder-free culture conditions, it required only 10-15 days. Also, in feeder-free culture conditions it took about 15 min to dispense cells in a 6-wells plate for the passages and the EBs formation, whereas, in the feeder condition it took $45 \mathrm{~min}$. Our protocol to differentiate hPSCs cultured in feederfree conditions will thus tremendously help laboratories and groups working in this field since feeder-free culture of hPSCs requires $70 \%$ reduced hands-on time than feeder cultures. The full protocol was tested and validated for hES WA09, T04-01A, T04-01B, T05-006, MiPS209-003, MiPS220-003 and we did not observe qualitative and quantitative differences between cell lines.

\section{CONCLUSION/DISCUSSION}

The goal of our study was to propose a rapid and efficient protocol to drive hPSCs toward the T lymphocyte fate. To do so, we assessed the effect of the culture conditions on the EB formation and hematopoietic induction. Feeder-free conditions were required to be GMP compatible and interestingly, all aspects of the differentiation setup were improved using feederfree conditions: hPSCs amplification, passaging time and EB formation. Those technical improvements did not impair efficiency. The yield was similar in feeder-free compared to feeder conditions, regardless of the source of hPSC lines (hESC: $n=2$, fibroblast-hiPSC: $n=6$, T-cell hiPSC: $n=4$ ).

Several studies reported the importance of EB size for the differentiation of hPSCs (Bauwens et al., 2008). In our study, the EB formation was done by hand scrape. With this technique, we mainly obtained two sizes of EBs, small ones around $100 \mu \mathrm{m}$ diameter and larger ones around $200 \mu \mathrm{m}$ diameter. In our hands, the size of EBs did not impact the differentiation efficiency. Therefore, we could keep the protocol simple and avoid using single PSC suspension and EB formation through culture in patterned microwells, such as AggreWells (Ng et al., 2005; Antonchuk, 2013). A critical factor indicating successful differentiation was the morphological aspect of EBs.

Using either feeder or feeder-free conditions, we observed two distinct populations, $\mathrm{CD} 34^{+} \mathrm{CD} 43^{+} \mathrm{CD} 45^{+} \mathrm{KDR}^{-}$ cells, which were hematopoietic progenitors, and $\mathrm{CD} 34^{+} \mathrm{CD} 43^{-} \mathrm{CD} 45^{+} \mathrm{KDR}^{-}$cells, which were in a less advanced state of hematopoiesis differentiation. We chose not to sort $\mathrm{CD} 34^{+} \mathrm{CD} 43^{+}$cells for seeding on OP9-DLL1/4. Indeed, our experience has shown that sorting $\mathrm{CD} 34^{+} \mathrm{CD} 43^{+}$ cells with FACS Aria is traumatic for the cells and results in significant mortality of these progenitors. In our hands, seeding the full disaggregated EB on OP9-DLL1/4 led to less progenitor

\section{Feeder Condition}

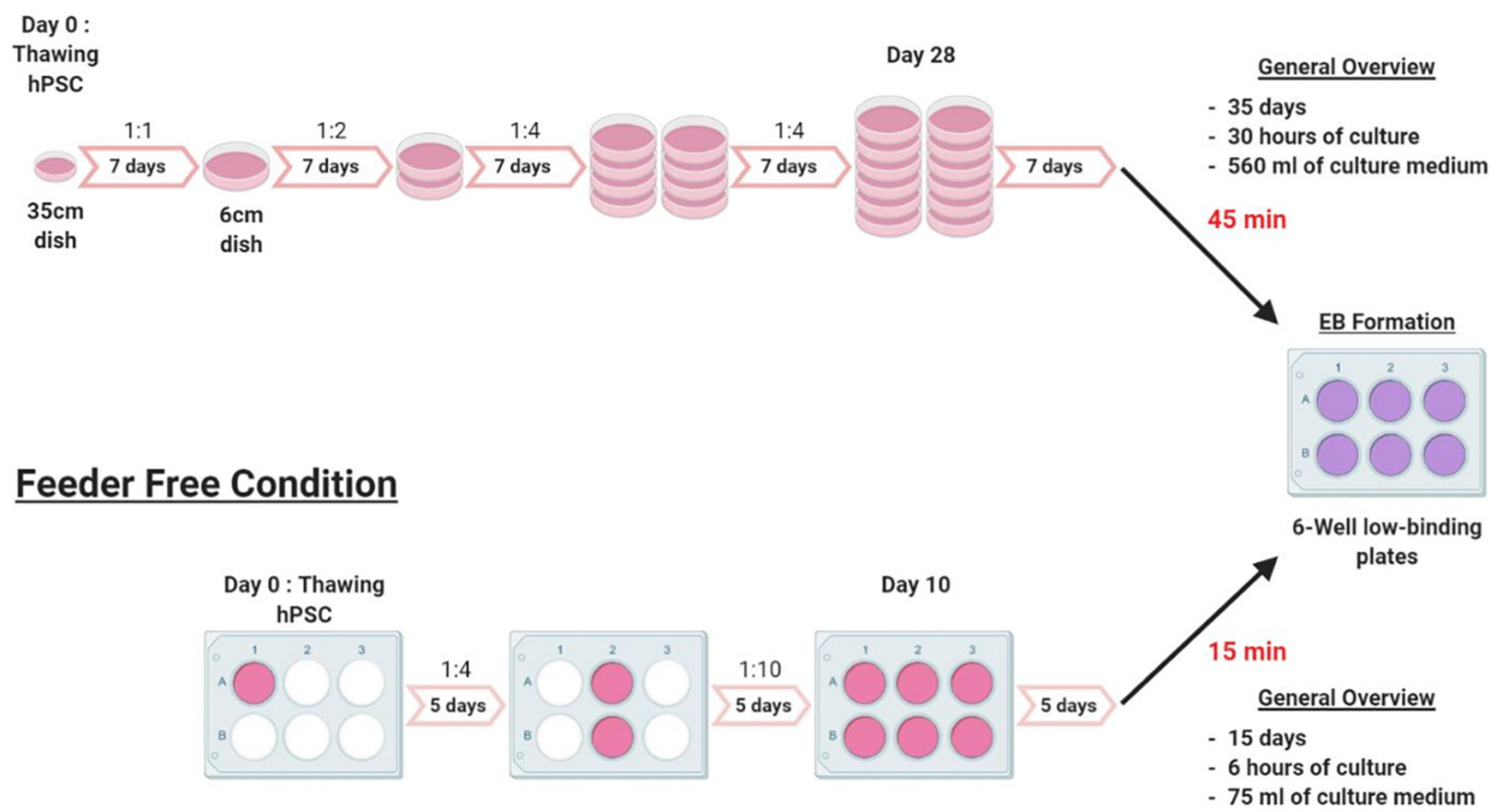

FIGURE 4 | Experimental outline. Schematic representation of the experimental outline in feeder and feeder-free culture conditions, from thawing to EB formation. The feeder condition takes 35 days of culture with a weekly passage at a ratio that varies from 1:1 to 1:4. EBs formation takes about $45 \mathrm{~min}$ from $12 \times 6 \mathrm{~cm}$ dishes to 6 -wells low binding plates of EBs. In feeder-free culture condition, the culture time is reduced to 15 days with a passage every 5 days at a ratio that varies from 1:4 to 1:10. The time for EBs formation is also significantly reduced from 45 min to only 15 min. 
mortality. We did not observe adverse effect of seeding all cells on the differentiation outcome.

We observe two cell populations that are likely to become $\mathrm{T}$ lymphocytes: $\mathrm{CD} 34^{+} \mathrm{CD} 43^{+} \mathrm{CD} 45^{+} \mathrm{KDR}^{-}$ and $\mathrm{CD} 34^{+} \mathrm{CD} 43^{-} \mathrm{CD} 45^{+} \mathrm{KDR}^{-}$subsets. The $\mathrm{CD} 34^{+} \mathrm{CD} 43^{+} \mathrm{CD} 45^{+} \mathrm{KDR}^{-}$will be directed toward the $\mathrm{T}$ lymphocyte fate by the contact with DLL1 or DLL4 ligands that activate the essential Notch signaling pathway (García-León et al., 2018) and by the cocktail of cytokines supplementing the culture medium (SCF, FLT31 and IL-7). We noticed that $\mathrm{CD} 34^{+} \mathrm{CD} 43^{-} \mathrm{CD} 45^{+} \mathrm{KDR}^{-}$cells still expressed high levels of endothelial markers such as PECAM1, VE-Cadherin, or YAP1 unlike $\mathrm{CD} 4^{+} \mathrm{CD} 43^{-} \mathrm{CD} 45^{+} \mathrm{KDR}^{-}$cells. Therefore, $\mathrm{CD} 34^{+} \mathrm{CD} 43^{-} \mathrm{CD} 45^{+} \mathrm{KDR}^{-}$cells might not have accomplished endothelium-hematopoietic transition. Nevertheless, Notch signaling could trigger $\mathrm{CD} 34^{+} \mathrm{CD} 43^{-} \mathrm{CD} 45^{+} \mathrm{KDR}^{-}$cells to transit to a progenitor state able to differentiate toward the $\mathrm{T}$ lineage (Kennedy et al., 2012; Sturgeon et al., 2014).

Two landmark studies compared DLL1 and DLL4 potency to induce T lymphocyte differentiation (Besseyrias et al., 2007; Mohtashami et al., 2010). They demonstrated that in human HCSs, DLL4 induced a Notch pathway response closer to the physiological conditions than DLL1 (Mohtashami et al., 2010). They also showed that DLL1 and DLL4 allowed differentiation toward the T lineage in a similar manner up to the pre-T CD25 ${ }^{+}$ stage but the maturation afterward was favored by DLL4 than by DLL1 (Besseyrias et al., 2007).

In our study, we did not observe any significant differences in the induction of $\mathrm{T}$ lymphocyte progenitors from hPSCderived hHSPCs in presence of DLL1 or DLL4. We concluded that DLL1 and DLL4 might have the same potency to drive early lymphopoiesis. In both cases, after 20 days of co-culture, we obtained precursors of the $\mathrm{T}$ lineage: $\mathrm{CD} 7^{+} \mathrm{CD} 4^{+} \mathrm{CD} 8^{+}$, $\mathrm{CD}^{+}{ }^{+} \mathrm{CD} 4^{+} \mathrm{CD}^{-}$and $\mathrm{CD}^{+}{ }^{+} \mathrm{CD} 4^{-} \mathrm{CD}^{+}$cells which did not express the $\mathrm{CD} 3$ and $\mathrm{TCR} \alpha \beta$ markers.

We showed by flow cytometry at day 35 and RNA-DGE sequencing analysis of differentiated cells at day 25, that these progenitors are bona fide DP $\mathrm{T}$ cells since they expressed key genes for lymphopoiesis, cytotoxic mediators and were able to further differentiated into $\mathrm{CD} 8 \alpha^{+} \mathrm{CD} 8 \alpha^{+}$cells and $\mathrm{CD} 4^{+} \mathrm{CD}^{-}$cells (SP) $\mathrm{T}$ cells. In addition, we detected the expression of $20-30 \%$ CD56 positive cells, likely natural killer lymphocytes, in line with previous reports (Nishimura et al., 2013; Themeli et al., 2013).

Advances in immune cell engineering are opening up new perspectives for the generation of custom synthetic $\mathrm{T}$ cells from hiPSCs. TCR acquisition by rearrangement during in vitro differentiation will no longer be a problem since antigen specificity can be given to hiPSCs and their T cell derivatives by means of a transgenic TCR (Minagawa et al., 2018). Themeli et al. have demonstrated the feasibility of generating functional in vitro and in vivo chimeric antigen receptor (CAR)-T cells by engineering T-iPSCs with a CAR before differentiation (Themeli et al., 2013). The use of CARs provides T-iPSCderived $\mathrm{T}$ cells customizable antigen specificity in a HLAindependent manner. Importantly, second and third generation CARs provide additional costimulatory signals and improve in vivo $\mathrm{T}$ cell activation, expansion and persistence. In principle, like CAR, T-iPSCs can also be genetically armed with cytokines, receptors and other regulatory molecules to confer optimal immunotherapeutic properties such as increased proliferation, and allogeneic HLA molecules can be knocked-out to generate stealth $\mathrm{T}$ cells that can evade detection and elimination by the host immune system (Nianias and Themeli, 2019).

Generation of $\mathrm{T}$ cell progenitors in vitro offers the opportunity to study lymphopoiesis. T cells are circulating in the blood which makes them easy to study. However, it remains extremely difficult to study the genesis of T cells in human. Recent strategies consist of performing single cell RNA sequencing from thymus and reconstituting fate trajectories (Park et al., 2020). This requires access to human thymuses and does not allow to functionally test hypotheses. Thus, in vitro generation of $\mathrm{T}$ cells would allow unprecedented investigation of lymphopoiesis.

To conclude, we established a robust, easy to implement and GMP friendly protocol for the generation of HSPCs, using feederfree hPSC culture conditions. This protocol yielded over 13\% of $\mathrm{CD}_{34}{ }^{+} \mathrm{CD} 43^{+} \mathrm{CD} 45^{+} \mathrm{KDR}^{-}$hHSPCs. We also established a protocol for $\mathrm{T}$ cell progenitors that would require further developments to be GMP-compatible, in particular culture conditions that would alleviate the need for OP9 cells. Our investigations showed that there were no major differences in the use of OP9-DDL1 or DLL4 cells for induction of lymphopoiesis. Like other groups before us (Kyttälä et al., 2016; Nishizawa et al., 2016), the only slight difference we observed was the variation between the different hPSC lines, likely due to the genetic background of each of the cell lines. Altogether, our protocol enables a much-needed approach to understand the development of the immune system in human. This opens new opportunities for drug screening, disease modeling and could provide an unlimited number of cells for regenerative medicine and cell therapy.

\section{DATA AVAILABILITY STATEMENT}

All datasets generated for this study are included in the article/Supplementary Material.

\section{AUTHOR CONTRIBUTIONS}

CG and LD: conceptualization, supervision, project administration, and funding acquisition. LF, AG, MT, CG, and LD: methodology and writing - review and editing. LF, AG, CG, and LD: validation. LF, AG, and CS: formal analysis. LF and AG: investigation. $\mathrm{OB}$ and XS: contributing essential reagent. LF: writing - original draft. All authors contributed to the article and approved the submitted version.

\section{FUNDING}

This work was funded by the Labex IGO (project «Investissements d'Avenir», ANR-11-LABX-0016-01), IHU-Cesti (project funded by the «Investissements d'Avenir», 
ANR-10-IBHU-005 as well as by the Nantes Metropole and Region Pays de la Loire). This work was supported by the "Paris Scientifique région Pays de la Loire" and by "Fondation pour la recherche médicale (FRM)".

\section{ACKNOWLEDGMENTS}

We thank the iPSC core facility of University of Nantes and Dionysia Kefala for their support for tissue culture. We also thank Juan-Carlos Zuniga-Pflucker and Mahmood Mohtashami

\section{REFERENCES}

Ackermann, M., Liebhaber, S., Klusmann, J.-H., and Lachmann, N. (2015). Lost in translation: pluripotent stem cell-derived hematopoiesis. EMBO Mol. Med. 7, 1388-1402. doi: 10.15252/emmm.201505301

Antonchuk, J. (2013). Formation of embryoid bodies from human pluripotent stem cells using AggreWell ${ }^{\mathrm{TM}}$ plates. Methods Mol. Biol. 946, 523-533. doi: 10.1007/978-1-62703-128-8_32

Bauwens, C. L., Peerani, R., Niebruegge, S., Woodhouse, K. A., Kumacheva, E., Husain, M., et al. (2008). Control of human embryonic stem cell colony and aggregate size heterogeneity influences differentiation trajectories. Stem Cells Dayt. Ohio 26, 2300-2310. doi: 10.1634/stemcells.2008-0183

Beddington, R. S., and Robertson, E. J. (1999). Axis development and early asymmetry in mammals. Cell 96, 195-209. doi: 10.1016/s0092-8674(00) 80560-7

Berenson, R. J., Andrews, R. G., Bensinger, W. I., Kalamasz, D., Knitter, G., Buckner, C. D., et al. (1988). Antigen CD34+ marrow cells engraft lethally irradiated baboons. J. Clin. Invest. 81, 951-955. doi: 10.1172/JCI113409

Besseyrias, V., Fiorini, E., Strobl, L. J., Zimber-Strobl, U., Dumortier, A., Koch, U., et al. (2007). Hierarchy of Notch-Delta interactions promoting T cell lineage commitment and maturation. J. Exp. Med. 204, 331-343. doi: 10.1084/jem. 20061442

Bézie, S., Charreau, B., Vimond, N., Lasselin, J., Gérard, N., Nerrière-Daguin, V., et al. (2019). Human CD8+ Tregs expressing a MHC-specific CAR display enhanced suppression of human skin rejection and GVHD in NSG mice. Blood Adv. 3, 3522-3538. doi: 10.1182/bloodadvances.2019000411

Bézie, S., Meistermann, D., Boucault, L., Kilens, S., Zoppi, J., Autrusseau, E., et al. (2017). Ex vivo expanded human non-cytotoxic CD8+CD45RClow/- tregs efficiently delay skin graft rejection and GVHD in humanized mice. Front. Immunol. 8:2014. doi: 10.3389/fimmu.2017.02014

Cerdan, C., Hong, S. H., and Bhatia, M. (2007). Formation and hematopoietic differentiation of human embryoid bodies by suspension and hanging drop cultures. Curr. Protoc. Stem Cell Biol. Chapter 1, Unit 1D.2. doi: 10.1002/ 9780470151808.sc01d02s3

Ditadi, A., and Sturgeon, C. M. (2016). Directed differentiation of definitive hemogenic endothelium and hematopoietic progenitors from human pluripotent stem cells. Methods San Diego Calif. 101, 65-72. doi: 10.1016/j.ymeth.2015.10.001

Flippe, L., Bézie, S., Anegon, I., and Guillonneau, C. (2019). Future prospects for CD8+ regulatory T cells in immune tolerance. Immunol. Rev. 292, 209-224. doi: 10.1111/imr.12812

Fournier, C., Martin, F., Zitvogel, L., Kroemer, G., Galluzzi, L., and Apetoh, L. (2017). Trial watch: adoptively transferred cells for anticancer immunotherapy. Oncoimmunology 6:e1363139. doi: 10.1080/2162402X.2017.1363139

Gaignerie, A., Lefort, N., Rousselle, M., Forest-Choquet, V., Flippe, L., FrancoisCampion, V., et al. (2018). Urine-derived cells provide a readily accessible cell type for feeder-free mRNA reprogramming. Sci. Rep. 8:14363. doi: 10.1038/ s41598-018-32645-2

García-León, M. J., Fuentes, P., de la Pompa, J. L., and Toribio, M. L. (2018). Dynamic regulation of NOTCH1 activation and Notch ligand expression in human thymus development. Development 145:dev165597. doi: 10.1242/dev. 165597 for kindly providing the OP9-DLL1 and DLL4 cells. We thank Jenny Greig for proofreading of the manuscript. We thank the core facilities GenoBIRD for performing the sequencing.

\section{SUPPLEMENTARY MATERIAL}

The Supplementary Material for this article can be found online at: https://www.frontiersin.org/articles/10.3389/fcell.2020. 577464/full\#supplementary-material

Holmes, R., and Zúñiga-Pflücker, J. C. (2009). The OP9-DL1 system: generation of T-lymphocytes from embryonic or hematopoietic stem cells in vitro. Cold Spring Harb. Protoc. 2009:pdb.prot5156. doi: 10.1101/pdb.prot5156

Kawamoto, H., Masuda, K., Nagano, S., and Maeda, T. (2018). Cloning and expansion of antigen-specific T cells using iPS cell technology: development of "off-the-shelf" $\mathrm{T}$ cells for the use in allogeneic transfusion settings. Int. J. Hematol. 107, 271-277. doi: 10.1007/s12185-018-2399-1

Kennedy, M., Awong, G., Sturgeon, C. M., Ditadi, A., LaMotte-Mohs, R., ZúñigaPflücker, J. C., et al. (2012). T lymphocyte potential marks the emergence of definitive hematopoietic progenitors in human pluripotent stem cell differentiation cultures. Cell Rep. 2, 1722-1735. doi: 10.1016/j.celrep.2012. 11.003

Kilens, S., Meistermann, D., Moreno, D., Chariau, C., Gaignerie, A., Reignier, A., et al. (2018). Parallel derivation of isogenic human primed and naive induced pluripotent stem cells. Nat. Commun. 9:360. doi: 10.1038/s41467-017-02107-w

Kyttälä, A., Moraghebi, R., Valensisi, C., Kettunen, J., Andrus, C., Pasumarthy, K. K., et al. (2016). Genetic variability overrides the impact of parental cell type and determines iPSC differentiation potential. Stem Cell Rep. 6, 200-212. doi: 10.1016/j.stemcr.2015.12.009

La Motte-Mohs, R. N., Herer, E., and Zúñiga-Pflücker, J. C. (2005). Induction of T-cell development from human cord blood hematopoietic stem cells by Delta-like 1 in vitro. Blood 105, 1431-1439. doi: 10.1182/blood-2004-04-1293

Langdon, Y. G., and Mullins, M. C. (2011). Maternal and zygotic control of zebrafish dorsoventral axial patterning. Annu. Rev. Genet. 45, 357-377. doi: 10.1146/annurev-genet-110410-132517

Lobach, D. F., Hensley, L. L., Ho, W., and Haynes, B. F. (1985). Human T cell antigen expression during the early stages of fetal thymic maturation. J. Immunol. 135, 1752-1759.

Miceli, M. C., and Parnes, J. R. (1991). The roles of CD4 and CD8 in T cell activation. Semin. Immunol. 3, 133-141.

Minagawa, A., Yoshikawa, T., Yasukawa, M., Hotta, A., Kunitomo, M., Iriguchi, S., et al. (2018). Enhancing T cell receptor stability in rejuvenated iPSCderived $\mathrm{T}$ cells improves their use in cancer immunotherapy. Cell Stem Cell 23, 850-858.e4. doi: 10.1016/j.stem.2018.10.005

Mohtashami, M., Shah, D. K., Kianizad, K., Awong, G., and Zúñiga-Pflücker, J. C. (2013). Induction of T-cell development by Delta-like 4-expressing fibroblasts. Int. Immunol. 25, 601-611. doi: 10.1093/intimm/dxt027

Mohtashami, M., Shah, D. K., Nakase, H., Kianizad, K., Petrie, H. T., and Zúñiga-Pflücker, J. C. (2010). Direct comparison of Dll1- and Dll4-mediated Notch activation levels shows differential lymphomyeloid lineage commitment outcomes. J. Immunol. 185, 867-876. doi: 10.4049/jimmunol.1000782

Moore, T. A., and Zlotnik, A. (1997). Differential effects of Flk-2/Flt-3 ligand and stem cell factor on murine thymic progenitor cells. J. Immunol. 158, 4187-4192.

Ng, E. S., Davis, R. P., Azzola, L., Stanley, E. G., and Elefanty, A. G. (2005). Forced aggregation of defined numbers of human embryonic stem cells into embryoid bodies fosters robust, reproducible hematopoietic differentiation. Blood 106, 1601-1603. doi: 10.1182/blood-2005-03-0987

Ng, E. S., Davis, R. P., Hatzistavrou, T., Stanley, E. G., and Elefanty, A. G. (2008). Directed differentiation of human embryonic stem cells as spin embryoid bodies and a description of the hematopoietic blast colony forming assay. Curr. Protoc. Stem Cell Biol. Chapter 1, Unit 1D.3. doi: 10.1002/9780470151808. sc01d03s4 
Nianias, A., and Themeli, M. (2019). Induced pluripotent stem cell (iPSC)-derived lymphocytes for adoptive cell immunotherapy: recent advances and challenges. Curr. Hematol. Malig. Rep. 14, 261-268. doi: 10.1007/s11899-019-00528-6

Nishimura, T., Kaneko, S., Kawana-Tachikawa, A., Tajima, Y., Goto, H., Zhu, D., et al. (2013). Generation of rejuvenated antigen-specific T cells by reprogramming to pluripotency and redifferentiation. Cell Stem Cell 12, 114126. doi: 10.1016/j.stem.2012.11.002

Nishizawa, M., Chonabayashi, K., Nomura, M., Tanaka, A., Nakamura, M., Inagaki, A., et al. (2016). Epigenetic variation between human induced pluripotent stem cell lines is an indicator of differentiation capacity. Cell Stem Cell 19, 341-354. doi: 10.1016/j.stem.2016.06.019

Park, J.-E., Botting, R. A., Domínguez Conde, C., Popescu, D.-M., Lavaert, M., Kunz, D. J., et al. (2020). A cell atlas of human thymic development defines T cell repertoire formation. Science 367. doi: 10.1126/science.aay3224

Politikos, I., Kim, H. T., Nikiforow, S., Li, L., Brown, J., Antin, J. H., et al. (2015). IL-7 and SCF levels inversely correlate with T cell reconstitution and clinical outcomes after cord blood transplantation in adults. PLoS One 10:e132564. doi: 10.1371/journal.pone.0132564

Radtke, F., Wilson, A., Mancini, S. J. C., and MacDonald, H. R. (2004). Notch regulation of lymphocyte development and function. Nat. Immunol. 5, 247-253. doi: $10.1038 /$ ni1045

Radtke, F., Wilson, A., Stark, G., Bauer, M., van Meerwijk, J., MacDonald, H. R., et al. (1999). Deficient $\mathrm{T}$ cell fate specification in mice with an induced inactivation of Notch1. Immunity 10, 547-558. doi: 10.1016/s1074-7613(00) 80054-0

Salvagiotto, G., Burton, S., Daigh, C. A., Rajesh, D., Slukvin, I. I., and Seay, N. J. (2011). A defined, feeder-free, serum-free system to generate in vitro hematopoietic progenitors and differentiated blood cells from hESCs and hiPSCs. PLoS One 6:e17829. doi: 10.1371/journal.pone.0017829

Slukvin, I. I. (2013). Hematopoietic specification from human pluripotent stem cells: current advances and challenges toward de novo generation of hematopoietic stem cells. Blood 122, 4035-4046. doi: 10.1182/blood-2013-07474825

Sturgeon, C. M., Ditadi, A., Awong, G., Kennedy, M., and Keller, G. (2014). Wnt signaling controls the specification of definitive and primitive hematopoiesis from human pluripotent stem cells. Nat. Biotechnol. 32, 554-561. doi: 10.1038/ nbt. 2915
Takahashi, K., Tanabe, K., Ohnuki, M., Narita, M., Ichisaka, T., Tomoda, K., et al. (2007). Induction of pluripotent stem cells from adult human fibroblasts by defined factors. Cell 131, 861-872. doi: 10.1016/j.cell.2007.11.019

Takahashi, K., and Yamanaka, S. (2006). Induction of pluripotent stem cells from mouse embryonic and adult fibroblast cultures by defined factors. Cell 126, 663-676. doi: 10.1016/j.cell.2006.07.024

Themeli, M., Kloss, C. C., Ciriello, G., Fedorov, V. D., Perna, F., Gonen, M., et al. (2013). Generation of tumor-targeted human $\mathrm{T}$ lymphocytes from induced pluripotent stem cells for cancer therapy. Nat. Biotechnol. 31, 928-933. doi: $10.1038 /$ nbt. 2678

Thomson, J. A., Itskovitz-Eldor, J., Shapiro, S. S., Waknitz, M. A., Swiergiel, J. J., Marshall, V. S., et al. (1998). Embryonic stem cell lines derived from human blastocysts. Science 282, 1145-1147. doi: 10.1126/science.282.5391.1145

Timmermans, F., Velghe, I., Vanwalleghem, L., Smedt, M. D., Coppernolle, S. V., Taghon, T., et al. (2009). Generation of T Cells from human embryonic stem cell-derived hematopoietic zones. J. Immunol. 182, 6879-6888. doi: 10.4049/ jimmunol.0803670

Vodyanik, M. A., Thomson, J. A., and Slukvin, I. I. (2006). Leukosialin (CD43) defines hematopoietic progenitors in human embryonic stem cell differentiation cultures. Blood 108, 2095-2105. doi: 10.1182/blood-2006-02003327

Zhu, M.-X., Wan, W.-L., Li, H.-S., Wang, J., Chen, G.-A., and Ke, X.-Y. (2015). Thymopentin enhances the generation of T-cell lineage derived from human embryonic stem cells in vitro. Exp. Cell Res. 331, 387-398. doi: 10.1016/j.yexcr. 2014.12.012

Conflict of Interest: The authors declare that the research was conducted in the absence of any commercial or financial relationships that could be construed as a potential conflict of interest.

Copyright (C) 2020 Flippe, Gaignerie, Sérazin, Baron, Saulquin, Themeli, Guillonneau and David. This is an open-access article distributed under the terms of the Creative Commons Attribution License (CC BY). The use, distribution or reproduction in other forums is permitted, provided the original author(s) and the copyright owner(s) are credited and that the original publication in this journal is cited, in accordance with accepted academic practice. No use, distribution or reproduction is permitted which does not comply with these terms. 